\title{
Symbolic representation of women on literary landscape: Textual analysis of the play Black is My Robe
}

\author{
Mahboob Alam | Muhammad Usman Askari* \\ School of Social Sciences and Humanities, University of Management \& Technology, Lahore, Pakistan. \\ * Correspondence Emails: usman.askari@umt.edu.pk | 15004119003@umt.edu.pk
}

\begin{abstract}
The article aims to explore the symbolic representation of women in Pakistani society and investigates the unconscious nature of patriarchy in which the image of women is painted as a material object. This study is grounded on the textual analysis of Shahid Nadeem's play "Black is My Robe." The story revolves around the exchange of a female character named Sundri with an Ox. Shahid Nadeem has employed symbols to unveil the image of a repressed woman in patriarchal society. He has exposed the constructed myths about the submissive status of woman in male-dominant society through his plays in Ajoka theatre. He highlighted certain traditional hierarchies which signify their influence in gender discrepancy and sex stratification in which women is considered just as a property. To highlight these discrepancies, this study is carried out under Sigmund Freud's theory of subconscious by using the literary technique of symbolism. The study has highlighted man's desire for prescribing the negation of any gender through symbolization and devoid of anticipating any unpleasant representation. This study concludes with the suggestion to emancipate and empower women and to demolish ridiculous ideals of patriarchy by moral verdicts.
\end{abstract} Article History

Received:

November 5, 2020

Last Revised:

March 30, 2021

Accepted:

April 9, 2021

Published:

April 28, 2021

Keywords: Ajoka theatre, patriarchy, societal norms, male domination, women representation, symbolic representation, gender objectification, theory of subconscious.

\section{How to Cite:}

Alam, M. \& Askari, M. U. (2021). Symbolic representation of women on literary landscape: Textual analysis of the play 'Black is My Robe.' Liberal Arts and Social Sciences International Journal (LASSIJ), 5(1), 139-153. https://doi.org/10.47264/idea.lassij/5.1.10

\section{Publisher's Note:}

IDEA PUBLISHERS (IDEA Journals Group) stands neutral with regard to the jurisdictional claims in the published maps and the institutional affiliations.

Copyright: () 2021 The Author(s), published by IDEA PUBLISHERS (IDEA Journals Group). This is an Open Access article published under the Creative Commons Attribution-NonCommercial 4.0 International License (http://creativecommons.org/licenses/by-nc/4.0/) 


\section{Introduction}

Human history has always witnessed the unjust inequality of Patriarchy and manifested how women's autonomy is segregated in every realm of the world devoid of any concrete justification (Bruckmüller \& Maike, 2020). This rubric of patriarchy also imposes dependency and subordination on females through institutionalized norms (Blumell \& Mulupi, 2020). Moreover, male dominated society has constructed their own absurd myths about the confinement of females' role to the domestic sphere (Minow, 2000; Benstead, 2020). The family and matrimonial laws are based on rituals and customs to maintain family duties, relationships, rights, and finances. These statutory and customary laws are backed by religious and social practices where men are given more preference over women. In this way women are becoming the victim of this structural violence (Minnich, 2020).

The dominance of patriarchy is a historical phenomenon. Such social inequalities are emerging worldwide. The manifestation of such family inequalities can be witnessed throughout the world where boys are given advantaged over girls and men over women at large. Family laws generally encompasses issues of marriage, custody, divorce, and inheritance but such laws mirror the devaluation of women in the society by its inequalities (Sultana, 2011; McCloskey \& Eisler, 1999).

Patriarchy has now clothed itself in the postmodern civilization but its way of operating is exactly the same it did in the past. The manifestations of patriarchal control, violence and domination have been diversified in the contemporary era. They now exist in emotional, cultural, psychological, and physical forms. The direct form of violence is physical violence while the passive form of violence is carried out thought educational, economic, racial, political, cultural, and religious means (Bahlieda, 2015).

Now its domain has become so resilient that it permeates the entire globe in all socio-economic and political factors. Patriarchy has advocated its supremacism throughout the world through the subjugation of female roles. Besides men tend to believe in patriarchy a universal phenomenon but in actual reality, the dominance of patriarchy is a historical phenomenon. It is a society, which standardized a framework for creating gender poles where the women are relegated as child bearer, not frontrunners (Christianson et al., 2020).

Pakistan is having an ethnic, geographic, and regional diversity. Gender inequality is common in Pakistani culture. Women are not considered as a homogenous group in this country. They are suffering from gender disparities in terms of education, health, and employment (Chaudhry, 2007). When Pakistan emerged as an independent state it was controlled by patriarchal and traditional forces. The feudal of Pakistan dominated the whole political machinery. In the process of state building women were being marginalized from political system. They were isolated, excluded and confined to domestic zones. Secular education was considered inappropriate for women. Only religious education was allowed within four walls of a home so that they can only manage house life (Khan, 2013; Jalal, 1991).

Family system in Pakistan is basically patriarchal which is deep-rooted traditional and cultural. Man is the dominant head of each family. He is responsible for the financially expenses of the home. On the other hand, women are assigned the domestic zone to nurture children and the maintenance of the households (Mahmood, 2002). 
Marriage is believed as an important moral and social obligation in Pakistan. Certain laws and customs are mandatory to govern the institution of marriage. The pattern of family formation and marriage system has been altered throughout the world due to global political and economic changes. These structural changes have been associated with modernization and globalization which give emphasis to social equality and individual freedom. Whereas Pakistan is also depicted a tradition-bound society. All social, economic and political inequalities are being shaped and influenced by ethnicity, caste, religion and class. In rural and tribal areas of Pakistan, the patriarchal customs maintain the supremacy of male over female. The status of a woman is like a commodity. Women can be sold or bought in marriages. Women may be exchanged to resolve the disputes (Critelli, 2012).

The woman image created in the mind of man is more of a subhuman. Patriarchy functions as a part of man's psyche (Joseph, 1996). Shahid Nadeem has exposed the realistic picture of male society in Pakistan where women are facing repression by the patriarchal society (Ali et al., 2011). He further introduced a modern theatre named "Ajoka Theatre" to highlight this issue of social stratification on a wider scale. He indicates how society is holding the supervision of mirror in drafting the image of both genders. It is fact-based that history remained biased towards both genders in prioritizing their contribution to life circle. In each part of the globe, there is a concept of gender discrimination but the intensity of patriarchal empiricism varies from region to region.

The research objectives of this study aim to investigate the role of society in undermining the status of women and to find out how society has influenced in prioritizing both genders differently in all socio-economic and political arenas. Keeping in view the above objective, the study tries to find the answers of the following two questions. What are the traditional hierarchies, which signify their influence in gender discrepancy and sex stratification where the role of a woman is merely confined to just any material object? What are the man's psychological factors, which lead to women subordination as animals?

\section{Literature review}

In this part, our concern is to find the identity roots of both genders and how fake myths were structured for the representation of woman image. The image of the woman has demarcated all realms of history based on cultural and biological merits. As nature, leads to the biological distinction of both sexes while the concept of gender always imposed by societal norms and cultural practices. For example, if we go back to history how the image of man is portrayed in Greek as a godlike figure but the image of the woman is portrayed as alien being, other and corrupt soul. Likewise, Hesiod who depicted the nature of a woman in his story as 'devilish beauty' through the 'Pandora Myth. Later, same conventions about woman's image were regulated in western traditions. Even the status of woman is standardized as mere a crafted object. Besides, the citizens of Thebes and Athens believed the inferior status of woman in their conscious that the origin of man's birth is a man, not woman. Moreover, the Clement of Alexandria summarized a set of principle for masculine authorities where men were idealized the symbol of actions while the woman is deliberated as a mark of suffer (Holmes, 2012).

This concept of gender binarism was secured in all realm of society (Dorius \& Firebaugh, 2010). A comprehensive outline of different ages of history displays how literature and myth had become the barometer for measuring the worth of women. In that barometer, the women were at the lowest level in judging social attitudes. Through the depiction of different genres 
of literature, he showed us the darker side of patriarchy towards females in all classical, Hebraic and Christian Traditions. Even the Old Testament believed females as a subsequent reflection. The man wants to see the image of a woman in his mind as a blind follower. Further St. Paul stressed that the business of any is to learn and to be silent. She is not supposed to teach anyone. Moreover, Martin Luther description about Adam as the lord of a living creature. He blamed Eve for spoiling everything. He has given reference from Shakespearean Tragedy 'Othello.' In this play, Desdemona was murdered by her husband because it was just supposed that she was a whore. One pathetic aspect of literature is that the woman was given the status of an animal which is being evolved from ape by mentioning the ninth species of females as ill-natured and horrid. The worth of a woman is depicted as animal or cattle in the Victorian era through the work Victorian Novel 'Mayor of Casterbridge where in the start of the novel the drunkard husband sold out his wife and daughter in the market just for few currencies (Attallah, 1987; Ruether, 2014).

Moreover, man has represented his conscious image as universal through exercising the fibre of patriarchy. The interest of society is solely one gender sided. The privileges of a male are prioritized in all socio-economic and educational factors. (Soman, 2009). This fibre of patriarchy did not come into being on its own rather it is constructed. This concept of dominance is carried on the silence of women. This silence leads to the status of women in society as a being having no existence and presence. The ideological forms assert certain regulations on women, which compel them to believe themselves as objects in each society. The image of a woman in man's conscious is just like an object, which can be replaced from one place to another place. Female has to live in such discourse, which belongs to others. She faces alienation because she cannot be allowed to accept his subjectivity. Everyone knows the worth of economics to exercise the wheel of life. Here our concern is to expose man's psyche that varies the image of any gender in his conscious and unconscious to meet his materialistic needs. The value of economics is necessary for building social relations and linkages. She argued that the Economy is one of the most eminent aspects of patriarchy in maintaining the relation between different genders. As we see gender from one perspective and class from another perspective. Class and gender both are incomplete without each other. Both are dependent on an ongoing process (Smith, 1987; Acharya, 2016).

The mythical constructions about the structure of women are as an object and source of fertilization. These myths are moving forward from generation to generation where the male figure is authoritative. It is the patriarchal society that constructs those ideologies to support the male domination and woman is marginalized as an exchange object between kinship members. Furthermore, fertility and sexuality are entirely under the control of men. Rowbotham further explains that these myths are constituted on the grounds of biological differences to maintain gender supremacy. Here we are analyzing the work of Rowbotham because she is mentioning the roots of patriarchy as universal and prehistorically (Rowbotham, 1983; Vasquezet al., 2017).

The other stereotype about women is constructed that they are alleged biologically inferior from men and man has created this bridge just to create a comfort zone for himself. This institution of the patriarchy is deliberated as trans-historic, transcultural, and universal to maintain its supremacy over females. Why do we feel need to capture the work of Acker in our dissertation as Acker discuss the agenda of social theory of feminism where she elaborated that such distinction between both genders is created by men to meet 'social necessity'. Moreover, she states that this barrier of gender division is established for male liberty and freedom. What 
criteria is standardized to maintain the social theory bases on biological distinction is irrational and the building of patriarchy can be dismantled through the liberation of females (Acker, 1989; Bruno, 2018)

Patriarchy has constructed a gender law placing the role of woman in sexuality and fertilization. Such a standard is constructed through a discourse clustering three ideas of sexuality, domesticity, and pathology. These constructions uphold such hierarchies which deliberate male superiority and normality whereas women are delineated as abnormal. Women are portrayed as dependent on their husbands economically. They are portrayed as fickle, emotional, impulsive and irrational while men are represented as the decision maker, logical and judgmental. In fact, these laws are evaluated to show the image of woman as deceitful (Carlen \& Worrall, Women's Justice? Gender, Crime and Justice, 1987)

Abramovitch (2005) discusses the status of woman as a sexual object according to psychological perspectives. Further, she quotes Lacan's views about woman existence that women do not exist. Moreover, she claimed that women are only as daughters of their fathers and wives of their husbands. Even she inserted Rowbotham's conventions that women were hidden from the map of history. In her research employed Winnicott's psychological perspectives where the role of the woman is depicted as object, not as a subject. The male is portrayed as a subject while the female is standardized as an object.

The woman is considered as the chief and primary structure of any family in reproduction, sexuality, the socialization of the children and in economic growth. So, on which priority one gender is believed an object and other is labelled as the subject. Even in case of a clinical investigation, the babies grow in the stomach of a mother in the same technique and setting. So, why both genders are perceived differently in society. In fact, the system of world basis on adversity but the treatment of one gender to another is unjust. The males as subjects always try to provoke females to realize themselves that they are their beneficiary and well-wisher but in reality, they always plan in their fantasies how to destroy their image (Mitchell, 1966).

In some parts of the world, patriarchal society has exercised two lethal traditions, which have demarcated the rights of woman, are dowry and polygamy. The amount of dowry, which is given to the bridegroom in the form of money and guarantees the future of the bride after marriage. If the bride's parents cannot afford the maximum amount of dowry for her daughter, then she will face an economic threat throughout the whole span of her life and further it leads to polygamy. The husband gives more priority only to that wife who accompanies with her more dowry in the form of wealth and households. Therefore, we can say that dowry in fact has become a tool, which measures the worth of female based on material possessions. Therefore, one can claim that dowry has become the source of competition between women. Dowry only decides where the future and worth of any woman in patriarchal society (Gaulin\& Boster, 1990; Barchi et al., 2018).

\section{Theoretical framework}

The theoretical framework of this study revolves around the implementation of Theory of Unconscious through the literary technique of symbolism. The unconscious theory comprises a set of ideas which are different from personal consciousness (Feingold, 1917). Unconscious thoughts pave the way for tacking tough decisions in the complex circumstances. However, the simple and common beliefs can be resolved through our conscious thoughts (Dijksterhuis \& 
Nordgren, 2006). Sigmund Freud designates unconscious as a distinctive entity as it accompanies both aggressive impulses and represses sexual feelings (Hirsch \& Roth, 2013). Freud further says that man's actual nature is primitive and savage. In primitive times, there have been certain thoughts, which were marked as a part of consciousness. Those thoughts encompass love, hate, creation, destruction and sexual derives. Now in present era, those old thoughts are believed as unethical and immoral social taboos. Those repressed thoughts have been pushed into the realm of unconsciousness. Thus, any individual under high repression tries to give those repressed thoughts a conscious state by employing any substitute or symbol (Schnier, 1953; Chase, 1911). As symbols vehicle the undesired intentions of any individual, which he cannot opt consciously.

Shahid Nadeem in his play 'Black is My Robe' exposed the unconscious reality of man by employing the symbol of an ox. The researcher is going to highlight that how the sexual repressed desires of a man compel him for exchanging an animal with a human being. Besides, this study aims to prove that the image of a woman in a man's mind is like an object. The worth of that object is materialistic which can be sold or exchanged. Furthermore, this study will prove that the worth of a woman is not more than a sex tool and child-producing machine in any patriarchal society like Pakistan. For this, the researcher has chosen the work of renowned playwright Shahid Nadeem who paid a significant contribution in presenting the concept of gender inequality in Pakistan through his play "Black is My Robe." In this play, he presented us a picture of Pakistani society where the worth of a woman not more than a chattel or a material object. Moreover, he showed the concept of traditional hierarchies like the class system and gender division through a range of characters.

\section{4. $\quad$ Research methodology}

This study is conducted through qualitative research methodology within post positivist paradigm. To find out the answers of research questions, two qualitative approaches i.e., descriptive and exploratory have been used. Being the review study, data is used mostly from primary and secondary sources. The primary data is extracted mostly from the governmental reports whereas secondary data is taken from journal articles, periodicals and books. The data analysis is done through the Documentary Analysis. The rationale behind the selection of this method is that it not only helps to handle data scientifically but clearly sets the parameters to handle the documentary sources in a coherent way. To remove the biases and prejudices of the sources, documentary analysis heavily draws on the four major tools of authenticity, credibility and representativeness and meaning as the basic means of qualitative control.

The first tool of quality control in documentary analysis is authenticity. Since the primary documents are taken from official sources, so there is no doubt about the authenticity of documents used in the study. It has helped the researcher to find the facts-based documents. Second tool has assisted to eradicate distortions and errors in the documents. Third tool of representativeness suggests the consultation of more documents to verify the themes under study. The fourth tool of meaning has helped to verify the evidence in a comprehensive way while adopting the compare and contrast technique to generate the themes. The final stage of data analysis is based on the breaking he data into bits and then combining all bits to generate the major themes to reach the conclusion. The conclusion becomes more authentic when it corresponds to every tool of data analysis. The documentary analysis has helped the researcher to suggest the ways through the emancipation of women could be ensured by removing the social structures and unwanted male dominated traditions. 


\section{Analysis and discussion}

The play was set in the remote village of Umarkot in Sindh. Through this play, one can realize the concept of humanity and gender equality through the action of a man named Allah Wasaya. He exchanged his wife with an ox to the owner peasant named Ditta. So, here we idealize that the worth of a woman not more than cattle in the patriarchal society where the word chastity, honour and freedom only for male figures. The play starts with the second marriage of Wasaya with Sohni who accompanied with her an ox. Wasaya looked happier not because of getting a new wife but also got an ox too. The value of an ox and his wife is categorized on the same level in the viewpoints of the second narrator. Such as Nadeem (2009) shows us a description as "Narrator 2: And the healthy ox is as important as a healthy wife" (p. 150).

Here it is evident that the image of a woman is like an ox in the mind of a man. After a few months, a tragic incident occurred with both Wasaya and Ditta. As the wife of Ditta suddenly died while on the other hand, the ox of Wasaya died too. On mourning day, Ditta, Wasaya and Villagers felt the loss of woman and animal ox with the same intensity. They cried not only for the wife of Ditta but also for the ox of Wasaya. So, one can idealize the position of humanity where it stands and how the status of a woman is not valued more than a pet animal. It also shows that loss of woman is not considered more than an animal which can be seen in his work as: "Villager: I thought you were talking about Wasaya's late ox. But the death of an ox is as tragic as that of a wife" (Nadeem, 2008, p. 161).

The study evaluates from previous research works that the image of the woman is demarcated as an exchange commodity of society through the construction of absurd myths in both prehistoric times and the contemporary era. To find out the factors which are responsible for creating such gender discrimination. As Adorno's views about women fragility when he penned a letter on 16 November 1937 to the Institute of Social Research (ISR) with a proposal. In this letter, he mentioned Erich from to whom he described the pathetic situation of women and man's psychology about women how they are being treated as an exchange commodity of society. He bemoaned women as stupid and irrational for being used as an instrument of capitalist hegemony. We state here Adorno's views because his perceptions have given us some clue about the actual influence of society and culture in constructing taboos for women's subordination (Ziege, 2003).

So, we have realized that the women are delineated as an object. They can be replaced and purchased at any time. Likewise, in the play when Wasaya lost his ox that was brought by his first wife Sohni, he felt hopeless and gloomy because the ox was linked with his profession of carrying water from one village to another. Now he was penniless because he has not any other source of income. So, the village matchmaker named Massi suggested a new way to Wasaya that he could divorce his first wife Sundri to get her exchange with another ox that owned Ditta by marrying Sundri with Ditta. Whereas Ditta needs a wife for the care of his children. Therefore, Nadeem (2008) narrates about perceptions of female character Massi: "Massi: Sundri is the price for the ox. You don't need Sundri and Ditta does not need the ox" (p. 165).

Morover, Bujok (1983) interprets the social hierarchies on which the whole social structure survives. Further, she implemented the perceptions of Wiedenmann (2002) where the status of a woman is described through a thorough investigation of human intentions towards animals. Here the purpose of human-animal relations merely bases on some particular goals and desires which may be physical or social needs. If the present animal is not meeting all man's 
requirements then its existence will be considered useless, unnecessary, strange and dangerous. The same mythology is applied to the existence of a woman by mentioning the course of human-animal relationships. The purpose of a woman ( as an animal) to serve the man. Otherwise, they are regarded as dangerous and less worthy. So, in this way, the only thing which women have is their body. Therefore, the men appoint them in the profession of slavery through extensive sexual exploitation. Further, it illustrates the fact that the nature of women and animal are the same because of having the same attribute such as pervasive, irrationality, madness, wilderness and dangerous.

The researcher has successfully tried to prove the unconscious nature of a man. The worth of a woman and an ox are both at the equilibrium position. Nadeem (2008) outlined the psyche of a patriarchal society where men just put their complete focus on the pursuit of their personal desires and goals. They do not even feel any trouble sacrificing the life of females for the accomplishment of their desires. They even will be ready to ignore all moral and ethical values for getting the state of perfection. Here Wasaya who divorced his wife without getting her permission for taking such disastrous action with her life. Wasaya denies her existence as her wife just because of materialistic gains which he desires in the form of an ox. So, he maltreated his first wife like an animal which he feels useless and less productive as compared to an ox. On hearing such bad news his first wife starts cursing them that she is a human being and she is being bartered just like an animal in the market. As he asserts "Sundri: You are unashamed. Aren't we women human? Don't we have rights? You are exchanging me with an ox. You don't have any morals" (Nadeem, 2008, p.169).

It shows where there is society there will be gender. Gender is socially constructed by the men to show the concept of masculinity by declaring women as the subject. Secondly, each society frames an ideological apparatus which is imprinted by authoritative and specialized people in the academic institutions or in society to publish a gender map for the continuity of the society. Furthermore, women are excluded from man's culture not only in the contemporary era but also in Western Europe women were excluded by men four or five hundred years ago. Men only idealized those standards and laws which are only beneficial for masculinity. The same tradition is being employed in discourse culture through written, printed and speech form. The women even were not allowed to raise their consciousness about their deprived situation. The approval of women's experiences is entirely in the custody of women. That is why one can see neither the specific contribution of women in devising any literary piece in history, philosophy, politics, and any poetic work.

This concept of domination and oppression of woman always exists in man's consciousness. He always wants his status acceptable and authoritative. To study the conscious nature of man as dominant and woman's conscious nature as subordinated likewise Rowbotham (1973) where she portrays the image of a woman in his consciousness as a moving object which he spins through his fingers. A man even always keeps the desire to get a hold of any female. She says "Men sense the contradiction in us. They observe desire to be prey. They notice how we want to put ourselves in their hands. They are afraid of becoming feminine because this means that other men will despise themselves" (p. 43).

The study explains the nature of patriarchal society where men only put a focus on those entities through which they can avail facilitation. Here, men have used women as a facilitator. When they think that the present woman is not demanding their needs, the society has given authority to replace that woman as a material object for getting alternate compensation. Moreover, the 
researcher explains that the concept of decision is only inherited by a patriarchal society where women are not allowed to cross the parameters of patriarchal society. Likewise, Nadeem (2008) dictates the discussion of female character Massi and Sohni as: "Massi: Why, whoever asks a woman's consent? Sohni: That is right. No one asks girls about such matters” (p. 169).

Society has idealized that cultural conflicts and cultures focus on the woman. Further, it investigates why a woman is not provided an opportunity for decision-making. Minow (2000) questioned odd cultural practices and norms of traditional societies due to which women issues arise and why the concept of polygamy is allowed to the masculine family for polygamy to compete the women. She further argues that it is the culture that divides male gender in public spheres and female genders in private spheres. Besides, she says that in 'third world countries' status of a woman is labelled as a labourer of households. The element of otherness is nominated for a woman in her work that the female is legitimized to murder for honour killing. The basic point of her work is to find the role of culture as culture is employed to 'excuse cruelty and violence.

A psychology perspective lies behind the idea of marriage why men feel the desire to get married to any women. Therefore, the answer to this question is that men marry women to fill the desire for sexual pleasure and women are depicted as a source of fertilization. If any woman who is not naturally capable to bear the babies, then patriarchy considers their primary right to snatch the status of woman and wife from any female. It means that the criteria to standardize any female as a woman or wife entirely basis on her reproduction system. If patriarchy finds any woman who is not meeting their actual notion of pregnancy, then the male figure has a right to replace her place in the home with another woman. Males generate these rules to suppress women in every sphere of life that males are superior biologically and mentally as compared to women. Such as in the play Opera says that Wasaya married the second time and abandoned his first wife because his first wife Sundri could not get pregnant. So, this justification is unethical. The parents of Sundry are dead. So, where she would go now and with whom she can share her state of being deprived and alienated. Nadeem (2008) says "Opera: When one didn't get pregnant, he brought another one. There was no respect for Sundri in the house. Where can she go? Her parents are no more. Who should she share her grief with?" (p. 169).

This study has recognized that women are marked as different beings from men based on their biological perspectives. So, the logic of this cultural convention that considers women inferior is exposed by Ortner(1974) where she gave a new perception about the distinction of both genders. She proclaimed woman as part of nature and man as an inheritance of culture. The culture believes it natural to suppress nature. Women are active members of society like men but they are stereotyped with such type of beings which are equitable to nature. Orter has taken the biological views of Beauvoir (1952) to prove the physiology of women as nature. The woman is enslaved to species which maintain themselves on biological grounds by only creating itself anew. These species only outcome in repeating the same life in many individuals. But the man who assures this repetition of life through aims and goal orientation. Further, the psyche of a woman is deliberated by equating them with animals that animals are free from the concept of project involvement because they are kept unaware of these things. Men serve the species just because of forming and beautify the shape and the model of the earth.

The other crucial aspect of societal thinking is portrayed through the actions of men how they impart a significant contribution to the destruction of the world in the form of hunting. Through 
which they take the life of any living being that is believed as prestigious. Whereas, the action of a woman to create a new life is declared inferior. Moreover, Orter has taken the viewpoints of Strauss( 1969) in order to show that image of women in the cognition of men as a sign. A woman will be acknowledged her position is at home as a generator of signs. Plus it is depicted that woman herself accepts her devaluation and surrender herself in front of the cultural ideologies. In the end, the animal-like existence of the woman has depicted through the analysis of her physiology that most of the woman's body involves natural function which surrounds the reproduction section. For instance, the woman has been homogenized with female mammal generates milk after pregnancy to feed the newborn babies.

Man has standardized economy and wealth a scale to suppress a woman in the home by confining her to domestic issues. When she will be confined to a particular domestic zone, she ultimately will be capable to earn wealth in the economic zone. For this, she will be dependent economically on her husband to meet her basic daily life needs. Therefore, the researcher is going to highlight that man plans such distribution in his imagination to suppress another gender woman and man has categorized woman in his mind as a caretaker of both husband and children. Such as in the play we observed that on the death mourning of Ditta's wife Ditta was not crying because of his infinite sentiments of compassion for his partner. However, he was crying that there is no one left behind who would feed the children and clean their clothes. It means men marry women to create facilities for their own selves. They have nothing to do with the feeling and sentiments of the women. "Ditta: Oh, dear departed wife. Why have you left the children motherless? Who will take care of them? Who will wash their clothes and bathe them?" (Nadeem, 2008, p. 160)

Nadeem in his play explained that man has planned firmly in his mind that only the woman is responsible for the household tasks and she is accountable for all the tasks like cleaning, washing clothes and feeding the children. Further, the woman is like an employee, who gets a job in the institution of man through marriage. However, when men think that the existing woman is incompatible, he considers it a moral obligation to outcast her from his life through adaptation of the divorce phenomenon and another marriage. Here in the play, the purpose of his second marriage with Sohni was solely for the care of children. He does not have his concerns with Sundri. He even converses with Sundri to take care of the children and he will be happy with her through this service. As he says, "Sundri: I know you are not happy here. But what could I do now? I needed a woman to look after my children. Just take care of the children" (Nadeem, 2008, p. 170).

It states that the male is responsible for the family as a breadwinner. Therefore, they claim their authority to determine the position and status of the women. The tag of the class is entitled to male figures because they declare themselves as financial supporters of their families. He insists that the process of Marxist feminism exercises under the umbrella of capitalism where the male is allocated toward the production phase and women are directed towards the reproduction phase. The reproduction part is deliberated as trivial as compared to the reproduction portion. So, we can say that men have adopted these two zones of labour to exploit the labour of women just for the survival of their dominance (Goldthorpe, 1983). But there is also an objection that women are more productive as compared to men because the ratio of housework production is more as compared to any other job. So, he declared women as direct supplier and producers while husbands are considered a member of expropriating class (Leonard, 1984). 
The study in the end shows the role of Ajoka theatre in exposing the evils of the patriarchal society through its performances as a political force. It is raising the consciousness of the people to remove the unjust principles from society. Shahid Nadeem is the executive director of the Ajoka theatre who started his career as a social and human activist. He is also recognized as the pioneer of political theatre in the sub-continent. He supported his radical theatre to abolish the unfair system of Pakistani society. He criticized the existing social taboos which impede the path of social change (Saleem et al., 2017).

The performance of Shahid Nadeem's plays in Ajoka theatre played a significant role in raising awareness among masses about their social issues (Altaf, 2012). Moreover, Shahid Nadeem in his plays used his artistic talent for social change. He transformed his dream of social change into entertainment. He has given his plays a life in the consciousness of the people. Through the plays, his basic idea of tolerance and humanitarian values, which have gone, disappeared both in past and present culture of Pakistan (Rahman, 2014). Therefore, the theatre movement holds its place in cultural conflict which questions issues like class structure, women rights, and language politics. The meaning of the Ajoka in Punjabi language is 'contemporary. It has played a crucial role in bringing closer a wide range of classes. Moreover, the subject matter of the Ajoka theatre is revolutionary as it arises questions concerning the present and past policies of the state which have curtailed the rights of secular individuals, leftist intellectuals, and the rights of the women (Afzal-Khan, 1988). In fact, Ajoka theatre uncovers the different dimensions of Pakistani culture through its performances. In the play Black is My Robe the notion of exchanging a woman with an ox seems very absurd and silly but the most important thing is that it highlights the extreme economic and social circumstances, which lead the happening of this act of exchange as a traditional norm (Shujrah, 2018)

\section{Conclusion}

In a nutshell, the study has proved that the psychological nature of man's unconscious how he fulfills his undesired wishes and the exercise of the policy of repression on the woman. In Shahid Nadeem's play, Black is My Robe the status of the woman is marked as a material object and the trafficking of the woman as an object by the man has been justified as a traditional norm to meet his financial needs. This attempt of trafficking where specifically woman was targeted shows the biased policies of the patriarchal society and the demarcation of all humanitarian and moral values. They are believed as the ultimate source of reproduction and fertilization. Just like in ancient times men used to drag the women in the caves by picking their hairs as if women were believed as animals.

The study explains that man has standardized the image of a woman as a tool to meet his sexual desire. He has the ultimate authority to suppress any women. Women are being accepted as servants and caretakers and servants in the minds of men. Their duty is merely to fertilize new babies, feeding the children and maintaining household issues. If any woman does not meet the criteria for fertilization, then her worth in society and the unconscious of a man is like a useless material object which can be replaced and purchased. The only thing due to which any man thinks that he is superior to any woman is just the biological distinction. The researcher used the work of Shahid Nadeem "Black is My Robe" to highlight the most crucial aspect of Pakistani society where the status of a woman is not more than living pet animals and material goods which can be exchanged, rented, or purchased. Like in the Play, we have idealized how Wasaya subjugated his first wife Sundri and snatched the status of womanhood by declaring 
her a barren land that cannot yield fruitful production. Secondly, men who marry women for their sexual desire and fertilization.

They believe women a child-bearing machine for the future generation. If she is not capable of bearing a child then the Patriarchal society has given men the right to kick them out from their houses. All rules and regulations of society are formulated by a patriarchal society where none dares to challenge the existing framework of society. The laws are constructed for the facilitation of men and to suppress women in every realm of life. As we know that the classification of both genders is a natural function. It is not in the hands of any society. So why patriarchal society has believed the male gender as superior and the female gender as inferior. This justification of society is biased and prejudiced. Society must classify both genders on morals and economics. Furthermore, it is not only bound naturally to certain women that they are not capable to bear children. Men also are medically unfit in the process of fertilization but here in our society, all blame goes towards women that their reproduction system does not work for bearing children. Therefore, men are provided preference to marry again with other women. Thus, we should strongly encourage this norm and the society must change its attitude towards this unethical brutal tradition.

The entity of desire exists in both genders. Both want to enter in a competition in the zone of life. But only masculinity is given chances to advance in the fields of life. This approach towards women is unfair and against the laws of nature. None has acquired the ultimate power to judge any individual just because of her biological differentiation. Women are human beings like men so both genders are given equal liberties in all spheres of life. Hence, society also constitutes such reforms in which both men and women are given equal chances in both domestic and economic spheres so that they can effort collaboratively for the prosperity of the whole nation. Besides the Ajoka theatre has paid a significant contribution to create awareness among the masses about social change and the enforcement of humanitarian laws without any biological superiority and societal pressure. Shahid Nadeem as a co-founder of Ajoka Theatre is a staunch supporter of equal human liberties. As an activist, he uncovered the social evils of Pakistani society where women are facing extreme violations of human rights in socio-political and economic zones. He performed his plays in Ajoka as a secular platform to target the people of every class where they observe this phenomenon of social oppression on women and the demolition of these social evils for the empowerment of women in Pakistani society.

\section{References}

Abramovitch, H. (2005). Review: The neglect of siblings in depth psychology. The San Francisco Jung Institute Library Journal, 24(2), 17-30. https://www.tandfonline.com/doi/abs/10.1525/jung.1.2005.24.2.17

Acharya, A.K. (2016). Trafficking of women for sexual exploitation in Mexico and their identity crisis. International Review of Sociology,26(2), 322-336. https://doi.org/10.1080/03906701.2016.1155357

Acker, J. (1989). The problem with patriacrhy. Sociology, 23(2), 235-240. https://doi.org/10.1177\%2F0038038589023002005

Afzal-Khan, F. (1988). Street theatre in Pakistani Punjab: The case of Ajoka, Lok Rehas, and the woman question. TDR (1988-), 41(3), 39-62. https://doi.org/10.2307/1146608

Ali, T. S., Krantz, G., Gul, R., Asad, N., Johansson, E., \& Mogren, I. (2011). Gender roles and their influence on life prospects for women in urban Karachi, Pakistan: A qualitative 
study. Global Health Action, 4(1), 1-9. https://doi.org/10.3402/gha.v4i0.7448

Altaf, K. (2012, July 01). Theater and social change in Pakistan: The plays of Shahid Nadeem. The South Asian Idea. https://thesouthasianidea.wordpress.com/2012/07/01/theaterand-social-change-in-pakistan-the-plays-of-shahid-nadeem/

Attallah, N. (1987). Women (1t ed.). Quartet Books.

Bahlieda, R. (2015). The legacy of patriarchy (chapter-1). In: The Democratric Gulag: Patriarchy, Leadership \& Education. Counterpoints, 488, pp.15-67. https://www.jstor.org/stable/45136330

Barchi, F., Winter, S., Dougherty, D., \& Ramaphane, P. (2018). Intimate partner violence against women in northwestern Botswana: The Maun women's study. Violence Against Women, 24(16), 1909-1927.https://doi.org/10.1177\%2F1077801218755976

Beauvoir, S. d. (1952). The Second Sex. Vintage.

Benstead, L. J. (2020). Conceptualizing and measuring patriarchy: The importance of feminist theory. Mediterranean Politics 26(2), 234-246 https://doi.org/10.1080/13629395.2020.1729627

Blumell, L. E., \& Mulupi, D. (2020). A playing field where patriarchy plays: Addressing sexism in South African and Nigerian newsrooms. Journalism Practice, 1-21. https://doi.org/10.1080/17512786.2020.1807391

Bruckmuller, S., \& Braun, M. (2020). One group's advantage or another group's disadvantage? How comparative framing shapes explanations of, and reactions to, workplace gender inequality. Journal of Language and Social Psychology,39(4), 457-475. https://doi.org/10.1177\%2F0261927X20932631

Bruno, L. (2018). National self-image as an obstacle to ensuring children's rights in the context of domestic violence and family law: The case of Sweden. Journal of Social Welfare and Family Law, 40(4), 426-440, . https://doi.org/10.1080/09649069.2018.1519156

Bujok, M. (1983). Animals, Women and Social Hierarchies: Reflections on Power Relations. University of California.

Carlen, P., \& Worrall, A. (1987). Gender, Crime and Justice. Open University.

Chase, H. W. (1911). Freud's theories of the unconscious. The North Carolina High School Bulletin, 2(3), 110-121.https://www.jstor.org/stable/43822402

Chaudhry, I. S. (2007). Gender inequality in education and economic growth: Case study of Pakistan. Pakistan Horizon, 60(4), 81-91. https://www.jstor.org/stable/41500094

Christianson, M., Teiler, Å., \& Eriksson, C. (2020). A woman's honor tumbles down on all of us in the family, but a man's honor is only his: Young women's experiences of patriarchal chastity norms. International Journal of Qualitative Studies on Health, 16(1), 1-14. https://doi.org/10.1080/17482631.2020.1862480

Critelli, F. M. (2012). Between law and custom: Women, family law and marriage in Pakistan. Journal of Comparative Family Studies, 43(5), 673-693. https://doi.org/10.3138/jcfs.43.5.673

Dijksterhuis, A., \& Nordgren, L. F. (2006). A theory of unconscious thought. Perspectives on Psychological Science, 1(2), 95-109. https://doi.org/10.1111\%2Fj.17456916.2006.00007.x

Dorius, S. F., \& Firebaugh, G. (2010). Trends in global gender inequality. Social Forces, 88(5), 1941-1968. https://doi.org/10.1353/sof.2010.0040

Feingold, G. A. (1917). The present status of the unconscious. The Monist, 27(2), 205-232. https://doi.org/10.5840/monist191727219

Gaulin, S. J., \&Boster, J. S. (1990). Dowry as female competition. American Anthropologist, 92(4), 994-1005. https://doi.org/10.1525/aa.1990.92.4.02a00080 
Goldthorpe, J. H. (1983). Women and class analysis: In defence of the conventional view. Sociology, 17(4), 465-488. https://doi.org/10.1177\%2F0038038583017004001

Hirsch, I., \& Roth, J. (1995). Changing conceptions of unconscious. Contemporary Psychoanalysis, 31(2), 263-276. https://doi.org/10.1080/00107530.1995.10746910

Holmes, B. (2012). Gender: Antiquity and its legacy. Oxford University.

Jalal, A. (1991). The convenience of subservience: Women and the state of Pakistan. In: D. Kandyoti (Ed.), Women, Islam and the state (pp. 77-114). https://link.springer.com/chapter/10.1007/978-1-349-21178-4_4

Joseph, S. (1996). Patriarchy and development in the Arab world. Gender \& Development 4(2), 14-19. https://doi.org/10.1080/741922010

Khan, S. (2013). Women and state laws and policies in Pakistan: The early phase, 1947-77. Proceedings of the Indian History Congress, 74, 726-733. https://www.jstor.org/stable/44158876

Leonard, D. (1984). Close to home: A materialist analysis of women's oppression. University of Massachusetts.

Leevi-Strauss, C., Sturmer, J. R., Bell, J. H., \& Needham, R. (1969). The elementary structures of kinship. Beacon.

Mahmood, N. (2002). Women's role in domestic decision-making in Pakistan: Implications for reproductive behaviour. The Pakistan Development Review, 41(2), 121-148. https://www.jstor.org/stable/41260457

McCloskey, L., \& Eisler, R. (1999). Family structure and family violence and nonviolence. Encyclopedia of Violence, Peace, and Conflict, 2, 1-11. https://doi.org/10.1016/B978-012373985-8.00067-2

Minnich, J. M. (2020). Societal violence against women and national insecurity: An Evaluation Study of Teaching a gendered security. Thesis submitted to School of Education, University of California. https://dx.doi.org/10.2139/ssrn.3476143

Minow, M. (2000). About women, about culture: About them, about us. Daedalus, 129(4), 125-145. https://www.jstor.org/stable/20027667

Mitchell, J. (1966). Women: The longest revolution. In: Women's Estate. New Left Review no. $40 . \quad$ https://www.marxists.org/subject/women/authors/mitchell-juliet/longestrevolution.htm

Mitchell, J. (2005, October). Theory as an object. Vol. 113, pp.29-38. The MIT Press. https://www.jstor.org/stable/3397652

Nadeem, S. (2009). Selected plays ( $1^{\text {st }}$ ed.). Oxford University.

Ortner, S. (1974). Is female to male as nature is to culture? Woman, culture, and society. Stanford University. https://doi.org/10.2307/3177638

Rahman, D. T. (2014, July 13). Thirty years of Ajoka. The News. https://www.thenews.com.pk/tns/detail/556646-thirty-years-of-ajoka-theatre

Rowbotham, S. (1983). Dreams and dilemmas: Collected writings. Virago.

Ruether, R. R. (2014). Sexism and misogyny in the Christian tradition: Liberating alternatives. Buddhist-Christian

Studies, 34,

83-94. https://www.jstor.org/stable/24801355

Saleem, S., Rafique, S., \& Shaheen, H. (2017). Politics of gender in Shahid Nadeem's selected plays. European Academic Research, 5(1), 454-468. http://euacademic.org/UploadArticle/3132.pdf

Schnier, J. (1953). Art symbolism and the unconscious. The Journal of Aesthetics and Art Criticism, 12(1), 67-75. https://doi.org/10.2307/426301 
Shujrah, M. ( 2018 , October 30). Theatre review: Kala Meda Bhes (Black are my Robes) by Ajoka Theatre. Young Magazine. https://www.youlinmagazine.com/article/theatrereview-kala-meda-bhes-(black-are-my-robes)-by-ajoka-theatre/MTI3Mw==

Smith, D. E. (1987). The everyday world as problematic: A feminist sociology. Northeastern University.

Soman, U. (2009). Patriarchy: Theoretical postulates and empirical findings, 58(2), 253-272. Sage. https://www.jstor.org/stable/23620688

Sultana, A. (2010). Patriarchy and women s subordination: A theoretical analysis. Arts Faculty Journal 4, 1-18. https://doi.org/10.3329/afj.v4i0.12929

Vasquez, E. A., Ball, L., Loughnan, S., \& Pina, A. (2018). The object of my aggression: Sexual objectification increases physical aggression toward women. Aggressive Behaviour, 44(1), 5-17. https://doi.org/10.1002/ab.21719

Wiedenmann, R. E. (2002). Die Tiere der Gesellschaft. UVK.

Ziege, E. M. (2003). Adorno to fromm. The fetish-character of 'woman': On a letter from Theodor W. Adorno to Erich Fromm (K. A. Diers, Trans.) The New York Public Library. http://www.logosjournal.com/adorno_letter.pdf 